\title{
MANAGEMENT OF THE PERSONNEL FUNCTION IN A CHANGING ENVIRONMENT
}

\author{
JUSTYNA MARIA MYSZAK \\ University of Szczecin, POLAND \\ e-mail: justyna.myszak@wzieu.pl
}

\begin{abstract}
RECEIVED
ACCEPTED

16 May 2018

JEL

CLASSIFICATION

M21, 015

KEYWORDS

the personnel function, business environment, micro-environment, macro-environment, market

ABSTRACT

The main goal of the article is to show the importance of an analysis of a company's environment in the context of the implementation of the personnel function. The study presents the structure of the environment (divided into micro- and macro-environment) in an orderly way, along with a description of individual elements in relation to the development of human capital in an organization. Exploration and monitoring of individual areas of the environment by organizations is at present a necessary condition, which not only fosters the formulation of a company's unique strategy, but also enables making the right decisions that guarantee survival on an extremely dynamic market.
\end{abstract}

\section{Introduction}

Contemporary, changeable market situation, which results from inter alia fast-paced globalization and internationalization of business, has made it relatively difficult for an organization to anticipate various opportunities and threats coming from the environment. Companies that want to survive on the market must anticipate the changes that take place in the environment in advance. Hence, a market environment analysis is helpful. For entrepreneurs, 
elements of the macro-environment, influencing the personnel function (also called the HR function), seem distant only seemingly. Market trends do not often attract the attention of managers who, in the course of managing the enterprise and being preoccupied with current or short-term problems, underestimate the importance of the macroenvironment analysis. Current problems in the labour market, related to the lack of employees and the need to "import" them from Ukraine and even Asian countries, are an good example here. What is more, there is a change in the tendency of transforming the employer's market into the employee's market. For the above reasons, the main goal of this article is to try to show the relation that exists between the company's environment and the personnel function implemented by the organization.

\section{External dimensions (the macr-envirponment factors) of the personnel function}

For the purposes of this study, a dichotomous approach to the business environment has been adopted, as shown in Figure 1. There is a kind of feedback between various determinants of business environment and that is why occurrence of changes in one of them may contribute to the occurrence of changes in the other. What is more, the boundary between micro- and macro-environment conditions is "fluid" and there is not any specific set of connections and impact of individual factors that influence the shape of the personnel function implementation. Therefore, the subject of theoretical reflection and practical solutions are on the one hand the same or similar problems related to the acquisition, evaluation, remuneration and development of employees (which occur in microenvironment). On the other hand, the approach to solving these issues is changing, mainly due to changes that take place"(Pocztowski, 2009) in the macro-environment.

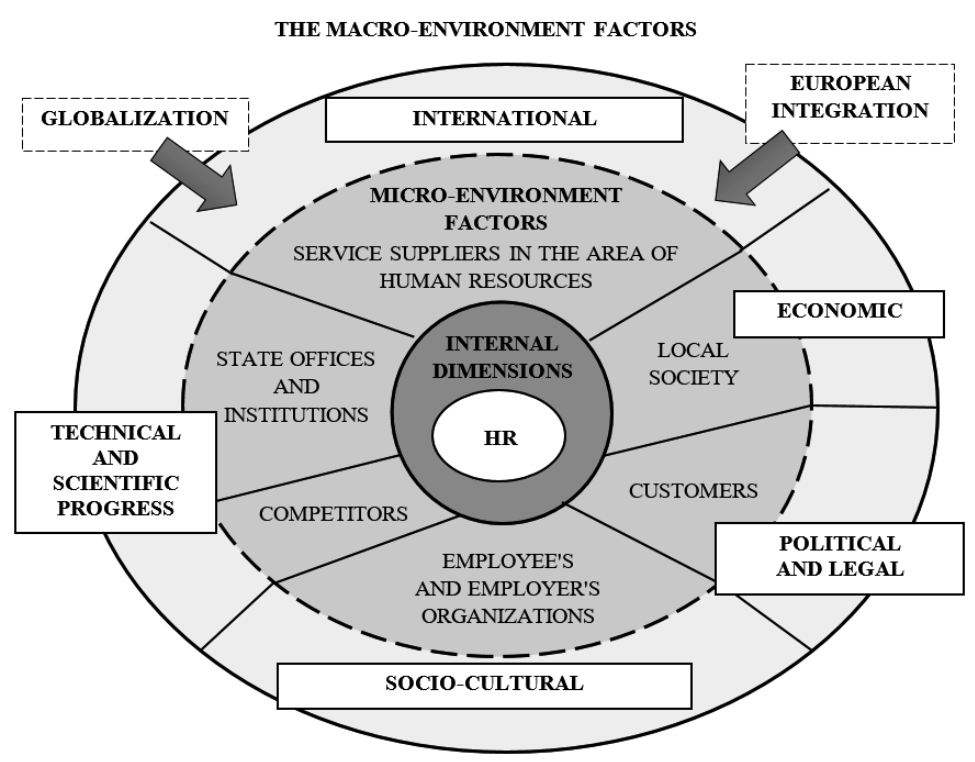

Figure 1. The components of the personnel function environment

Source: own work based on Pawlak (2011), p. 51, and Griffin (2012), p. 60. 


\section{Economic determinants}

The economic environment of an enterprise includes all economic phenomena that are shaped by the government's economic policy. They include such indicators as: economic growth rates, interest rates, unemployment rate, exchange rates, inflation level, foreign trade balance and many others (Chrisidu-Budnik, 2005), which will affect the organization and consumers with varying intensity. For example, under high inflation the prices of products increase as it is related to even more expensive acquisition of resources by companies. Moreover, consumers are not willing to borrow money at high interest rates and organizations have to pay more for a loan. High unemployment, on the other hand, allows companies to introduce a very selective recruitment policy (Wajda, 2003), which enables selecting an employee appropriate to a vacant position.

The issue of the economic situation, which has a very strong impact on employment (depending on the phase in which a given economy is in given time) is also significant. For example, in the expansion phase (economic recovery), organizations are more willing to invest, which directly translates into an increased demand for labour, and thus a creation of new workplaces, with the final effect being a drop in unemployment. As rightly noted by $Z$. Pawlak (2011), "fast economic growth, increase in the company's income also creates opportunities for fast increase of earnings, as well as developing the sphere of social and living benefits for the benefit of employees".

\section{Political and legal determinants}

Political and legal determinants in each country are of high importance because they contribute to ensuring socio-economic order. Depending on the adopted rules (as well as the honesty of state authorities in enforcing them), these regulations will affect the functioning of individual enterprises to a lesser or greater degree. It follows from its definition that the political and legal dimension "includes the state regulation of economic activity and relations between the state and economy. It is defined by the constitutions and laws of the countries in which the organizations conduct their activities, in particular by legislation regarding companies, antitrust and tax regulations"(Bendkowski, Bendkowski, 2008). The legal regulations that significantly affect human resources management in the organization include, among others: labour law regulations, civil law provisions, acts on trade unions, the act on the promotion of employment and labour market institutions, commercial companies law, provisions of tax law and many others, such as administration, insurance or financial law regulations (Pocztowski, 2007).

\section{Socio-cultural determinants}

In the literature on the subject, the authors very often separate the above conditions by analysing each one separately. They often distinguish an additional dimension, namely a demographic one. For the purposes of this study, however, it was decided to combine the above determinants because the correlation that exists between them is extremely strong. Changes in the socio-cultural determinants should be observed over a longer period of time. Parameters characterizing the social environment, which include (Gołębiowski, 2001):

- the level of civilization, i.e. the level of education and qualifications, the health status of the society, the state of security of citizens, the state of social security,

- social attitudes, lifestyle, consumption patterns, i.e. attitude to work, the model of spending free time, the importance of the family, functions of a woman in the family directly affect cultural determinants. 
For example in case of attitude to work, the organizational culture "covering all values, norms of rules, behavioural patterns characteristic for employees in a given organization and affecting their actions and behaviours" (Pocztowski, 1998) will be of high importance. In addition, the issue of the culture of a nation is also significant. It "is not identical with the culture of the organization, but to a certain extent, the culture of the organization will reflect the dominant values of the culture of the country in which the organization operates" (Robbins, Judge, 2012). Thus, the socio-cultural factors characterizing a given country exert an extremely significant influence on shaping certain patterns of behaviours, values or ethical and moral norms, which in turn translate into the attitude of people to work and their approach to the implementation of the personnel function.

\section{Technical and scientific progress}

Scientific and technical determinants contribute to revolutionary changes in the sphere of functioning of both economy and each organization. At present, companies which do not enjoy this benefit, lose their value. Technical and scientific progress is not only the source of creation of new products and services, but also new qualifications which often decide about their competitive advantage. The facts show, however, that along with scientific and technical progress, the replacement of humans in the work process (including new technologies) is noticed, which directly translates into employment reduction. If employees want to keep their current job, they also have to keep up with progress, for example by improving their qualifications and professional skills or gaining new ones (Janowska, 2010). For instance, in recent years, thanks to the dynamic development of such areas of technology as IT and telecommunications, many new job offers, related to previously unknown professions and specialties, have appeared on the labour market. These include among others tele-working, which in many traditional professions has profoundly transformed not only the system of working time, but also its organization. It should therefore be pointed out that technical and scientific progress indisputably allows for free flow of intellectual capital between countries (Pawlak, 2011), which is a premise of for inter alia fast-paced globalization.

\section{International determinants - globalization}

Nowadays international determinants, constituting a specific element of the macro-environment, play a significant role in the life of almost every organization (whether it is ready for it or not). This is "a dimension that affects the state in which organizations that are influenced by economic activity in other countries or are already involved in this activity" (Wajda, 2003). For example, multinational companies such as General Electric, Sony or even Procter \& Gamble not only are influenced by the conditions prevailing in ("foreign") international markets, but they are also directly affected by them. Analysing for instance McDonald's restaurant chain, one can easily find information that currently the company operates in 119 countries and serves around 58 million customers a day (www.manager.money.pl). It also plays a significant role in Poland, as opening of 402 restaurants in over 150 cities has resulted in the employment of over 22,500 people (www.mcdonalds.pl), which contributes to the creation of new workplaces and decrease in unemployment. The reasons for which enterprises want to expand their business activity on new sales markets are also seen in the strength of competition. "Even companies operating only in one country can meet on the domestic market with foreign competition or use materials or production equipment imported from abroad" (Griffin, 2004). 
The international determinants are directly related to inter alia technical and scientific determinants, which, as mentioned above, created the possibility of not only free movement of techniques (machines, devices, transport, etc.), information, but also important intellectual capital between countries. This, in turn, is the premise of globalization. According to G.W. Kołodko (2001), "Globalization is a process of creating a liberalized and integrated global market for goods and capital and the shaping of a new international institutional order, serving the development of production, trade and financial flows on a global scale." One can be tempted to supplement this definition and state that it also serves the development of the flow of human (intellectual) capital, which affects the development of "universal" international personnel function.

In the context of human resources management, the definition proposed by A. Pocztowski (2007) seems to be more adequate, because according to the author "globalization is the process of integration of the world economy, taking place among others through trade, cooperation of governments and enterprises, international circulation of money, confluence of cultures and the similarity of lifestyles and social institutions". Thus, it means that as a result of fast-paced globalization, organizations of the 21st century face more and more new challenges that are particularly visible in the sphere of company management. The higher the degree of enterprise globalization, the more noticeable are the effects of decisions taken, which, in addition to the fact that they concern more complex tasks, additionally have a greater range of impact. The question of the personnel function is not without significance. As a result of globalization, the macro-environment determinants are constantly being transformed. This refers to the migration of people (free movement of capital), which enforces an introduction of legal changes in the area of the labour market and employment (Pocztowski, 2007).

\section{External determinants of human resources management}

The external micro-environment determinants are formed by specific organizations, institutions or groups that influence the functioning of a given enterprise (Bendkowski, Bendkowski, 2008). The impact and selection of specific elements of the institutional environment of course depends on many factors, including the type of business. Nevertheless, Table 1 presents common elements of the micro-environment with a brief characteristic of their impact on human resources management in the organization.

Table 1. Micro-environment determinants

\begin{tabular}{cl}
\hline Elements & \\
\hline 1 & Characteristics \\
\hline & shows, among others: \\
& - the "qualitative" structure of available human resources, i.e. relevant experience, qualifications, skills, \\
& competences, \\
& - "quantitative" structure, i.e. what the demand for labour is, and \\
& - market price at any given time. \\
& These factors will significantly affect decisions made by enterprises in the field of human resources, including: \\
& - finding appropriate sources of employee selection, \\
- determining the level of remuneration, & \\
- selecting and conducting appropriate training, \\
- the scope and level of social and welfare benefits
\end{tabular}


Currently, clients exert a great influence not only on the functioning of the organization, but also on human resources management as:

- they formulate specific product and quality requirements,

- they expect fast, professional and cultural service.

Customers

As a result of this:

- great emphasis is placed on the recruitment and selection process of staff, especially in companies where there is direct contact with the client, e.g. banks, hotel or catering services,

- implementation and conduction of programs, methods and various forms of training, during which employees, for example through staging, demonstrations, trainings (and many other forms), gain appropriate knowledge and skills in conducting conversations with clients, learn how to approach customers and behave in abnormal situations etc.

A particularly visible effect can be seen in the area of:

- selection of employees - some employers unofficially seek candidates among employees of the competition, proposing a more interesting job offer. At present, job offers, e.g. for the position of a sales representative, very

Competitors often include the following condition: "a candidate with own customer base wanted",

- remuneration and working conditions - too low remuneration or unfavourable working conditions are often the reason why employees leave their jobs (even the key ones) and joining competing companies. Thus, sufficient market data in the above-mentioned scope is indispensable.

They include above all:

- trade unions and professional associations,"

Employee's organizations

- non-company trade unions, e.g. industry, inter-branch, regional, national trade unions associations (federations) and national inter-trade trade union confederations

They include above all:"

- the Confederation of Polish Employers (KPP),

- the Polish Confederation of Private Employers - Lewiatan (PKPP Lewiatan),

- Business Center Club,

Employer's organizations

- the Polish Craft Association (ZRP).

Their task is, among others, to protect the interests of associated members, representing employers towards the state,

self-government and trade unions, conducting collective bargaining, concluding collective labour agreements and other agreements

They include in particular:

- personnel consulting companies which provide consulting services and deal with recruitment and HR selection, manage personnel matters by means of outsourcing in an objective and professional manner,

- IT companies which deal with the production and sales of computer software that supports dealing with personnel matters. Depending on the software purchased by the company, systems include various activities, such as

Service suppliers in the area of human resources planning, recording, employee evaluation, employment analysis or calculation of wages in the organization,

- training companies, whose scope of vocational education and training is as diverse as their number. These include above all: training and vocational training institutions, schools for managers, foundations and professional associations, as well as universities,

- professional publications, all kinds of literature, such as books, magazines presenting knowledge in the field of human resources management, prevailing development trends on the market, applied methods in practice, tools, concepts, popular profiles of famous managers, personal advisers, etc.

These include in particular:

- the Ministry of Labour and Social Policy,

- Employment Offices (province and poviat ones),

- the National Labour Inspectorate,

State offices and institutions - Labour inspectorates,

- State Sanitary Inspection,

- the Office of Technical Inspection,

- Social Insurance Company (ZUS),

- Labour and social security courts

"More on this subject in: http://www.zwiazekzawodowy.pl.

"More on this subject: http://zielonalinia.gov.pl/-/jakie-organizacje-pracodawcow-funkcjonuja-w-polsce-11840.

Source: own study based on Pawlak (2011), 55-59. 


\section{Conclusions}

In conclusion, it is worth emphasizing that the abovementioned conditions significantly interweave and permeate each other, constituting a kind of chain of interaction. For example, the economic environment of a given country, i.e. the unemployment rate, economic growth rates or interest rates directly depend on the policy pursued in a given country. In the context of, for instance, high unemployment rate, people often migrate in order to seek new and more attractive working conditions abroad. Such actions exert influence on demographic, sociocultural or even international determinants, which in turn are related to the policy of the European Union. Modern organizations operating in dynamically changing conditions must not only become familiar with the principles that dictate particular conditions, but also have to constantly monitor phenomena occurring both on the local and global market. Understanding, analysing and drawing the right conclusions from both micro- and macro-environment determinants (that basically are more tangible) can provide the company with many valuable information that, if used in an appropriate manner, can contribute to the professional implementation of the personnel function.

\section{References}

Bendkowski, J., Bendkowski, J. (2008). Praktyczne zarządzanie organizacjami. Kompetencje menedżerskie. Gliwice: Wyd. Politechniki Śląskiej.

Chrisidu-Budnik, A. (2005). Organizacja i jej otoczenie. In: A. Chrisidu-Budnik, J. Korczak, A. Pakuła, J. Supernat, Nauka organizacji i zarządzania. Wrocław: Kolonia Limited.

Gołębiowski, T. (2001). Zarządzanie strategiczne. Planowanie i kontrola. Warszawa: Difin.

Griffin, R.W. (2004). Podstawy zarządzania organizacjami. Warszawa: Wydawnictwo Naukowe PWN.

Griffin, R.W. (2012). Management. 11th Edition, South-Western Cengage Learning.

http://manager.money.pl/marki/mcdonalds.

http://www.zwiazekzawodowy.pl.

http://zielonalinia.gov.pl/-/jakie-organizacje-pracodawcow-funkcjonuja-w-polsce-11840.

Janowska, Z. (2010). Zarządzanie zasobami ludzkimi. Warszawa: PWE.

Kołodko, G.W. (2001). Globalizacja a perspektywy rozwoju krajów posocjalistycznych. Toruń: Dom Organizatora TNOiK.

Pawlak, Z. (2011). Zarządzanie zasobami ludzkimi w przedsiębiorstwie. Warszawa: Poltext.

Pocztowski, A. (1998). Zarządzanie zasobami ludzkimi. Zarys problematyki i metod, Kraków: Antykwa.

Pocztowski, A. (2007). Zarządzanie zasobami ludzkimi. Strategie - procesy - metody, Wydanie II zmienione. Warszawa: PWE.

Pocztowski, A. (2009). Tworzenie wartości dla interesariuszy w obszarze funkcji personalnej. Zeszyty Naukowe Uniwersytetu Ekonomicznego w Krakowie, 810, 5.

Robbins, S.P., Judge, T.A. (2012). Zachowania w organizacji. Warszawa: PWE.

Wajda, A. (2003). Organizacja i zarządzanie. Warszawa: PWE.

www.mcdonalds.pl.

Cite this article aS: Myszak, J.M. (2018). Management of the personnel function in a changing environment. European Journal of Service Management, 3 (27/1), 165-171. DOI: 10.18276/ejsm.2018.27/1-20. 